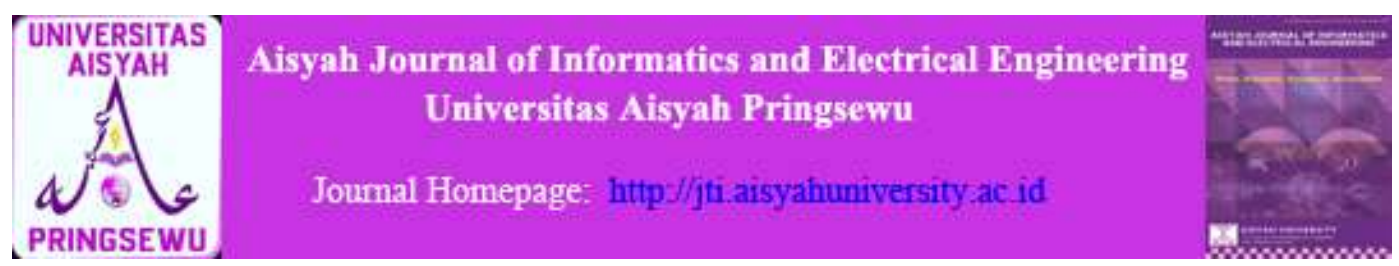

\title{
Pengenalan Pola Berbasis Segmentasi Citra Menggunakan Algoritma Fuzzy C-Means Dan K-Means
}

\author{
Tahta Herdian Andika ${ }^{1}$ ) \\ Program Studi Teknik Informatika, Fakultas Teknologi dan Informatika \\ Universitas Aisyah Pringsewu \\ e-mail: tahta.herdian.a@gmail.com
}

\begin{abstract}
Abstrak
Segmentasi merupakan salah satu bagian penting dalam analisis citra, karena pada prosedur ini gambar/citra yang diinginkan akan dianalisis untuk proses yang lebih lanjut agar lebih mudah di analisis gunat ujuan selanjutnya, misalnya pada pengenalan pola.Segmentasi citra yang merupakan bagian dari analisis citra digunakan untuk membagi sebuah citra menjadi beberapa bagian dan mengambil sebagian objek yang diinginkan.Salah satu teknik dalam segmentasi citra adalah dengan clustering. Clustering adalah suatu usaha untuk melakukan pengelompokan data berdasarkan kelas dan merupakan metode mengelompokkan atau mempartisi data dalam suatu dataset.Segmentasi citra berbasis clustering pada penelitian ini menggunakan metode K-Means dan metode Fuzzy C Means. K-Means merupakan metode yang simple dan cepat perhitungannya, sedangkan Fuzzy C-Means merupakan algoritma yang populer digunakan dalam teknik Fuzzy Clustering.Penelitian ini untuk mengetahui metode yang paling optimal dalam melakukan segmentasi citra. Sebelum melakukan segmentasi terlebih dahulu menentukan ruang warna menggunakan CIELab. Identifikasi data uji menggunakan dua pendekatan, yaitu analisis bentuk dan analisis tekstur.Hasil pengujian menunjukan algoritma K-Means menghasilkan segmentasi untuk identifikasi yang lebih baik dari pada Fuzzy C Means karena menghasilkan nilai yang hampir sama atau mendekati dengan nilai ekstraksi ciri citra yang tersedia.
\end{abstract}

Kata Kunci : segmentasi, fuzzy c means, k-means, clustering 


\section{Pendahuluan}

Segmentasi merupakan salah satu bagian penting dalam analisis citra, karena pada prosedur ini gambar/citra yang diinginkan akan dianalisis untuk proses yang lebih lanjut agar lebih mudah di analisis, misalnya pada pengenalan pola.Segmentasi citra yang merupakan bagian dari analisis citra digunakan untuk membagi sebuah citra menjadi beberapa bagian dan mengambil sebagian objek yang diinginkan.Pada bidang pengolahancitra, segmentasicitra mengacu pada proses pembagian citra digital ke dalam multiple region (himpunan piksel). Tujuan akhir dari segmentasi adalah menyederhanakan suatucitra agar citra tersebut dapat lebih mudah dianalisis. Salah satu teknik dalam segmentasi citra adalah dengan clustering. Clustering melakukan pengelompokan data berdasarkan kelas dan merupakan metode mengelompokkan atau mempartisi data dalam suatu dataset.Terdapat beberapa metode clustering yang digunakan untuk menyelesaikan permasalahan tentang segmentasi citra antara lain Metode Watershed, metode Chan Vese, algoritma Fuzzy C-Means, PSO (Particle Swarm Optimization), DPSO (Darwinian Particle Swarm Optimization), FODPSO (Fractional-Order DPSO)dan Kmeans.

Terdapat faktor-faktor tertentu dalam segmentasi citra yang memberikan hasil yang kurang memuaskan pada suatu citra tertentu. Hal ini dapat dipengaruhi oleh beberapa faktor yang terdapat pada citra itu sendiri seperti citra yang mengalami degradasi atau citra yang warnanya kabur, pencahayaandan citra terdapat noise. Dan juga dapat disebabkan oleh algoritma-algoritma yang digunakan belum mampu melakukan segmentasi citra dengan baik. Salah satu metode segmentasi citra yang belum mampu atau perlu dikembangkan lagi adalah metode watersheddan metode chan \& vese. Metode watershed merupakan salah satu metode dalam segmentasi citra yang membagi citra menjadi region yang berbeda dengan menggambarkan citra sebagai relief topografi. Metode watershed menghasilkan terlalu banyak region yang menyebabkan bagian penting objek terpisah atau disebut oversegmentasi, sehingga perlu dilakukan pengembangan metode [1]. Fuzzy C-Means merupakan algoritma yang populer digunakan dalam teknik fuzzy clustering. Metode algoritma Fuzzy C-Means untuk segmentasi citra dilakukan dengan menggabungkan beberapa algoritma optimasi atau algoritma metaheuristik seperti genetic algorithm (GA)[2].Sedangkanuntuk KMeans merupakanmetode yang simple dan cepat perhitungannya [3].

Berdasarkan dari semua latar belakang yang telah dibahas sebelumnya, maka penulis tertarik untuk mecobamelakukan eksperimen mengevaluasi peforma dari segmentasi dengan menggunakan algoritma Fuzzy C-Means kemudian melakukan perbandingan dengan algoritmaK-Means.

\section{Metode Penelitian}

Alur analisis penelitian dilakukan berdasarkan permasalahan yang akan ditangani oleh sistem, dimana sistematika penelitian yang digunakan pada penelitian ini sebagai berikut:

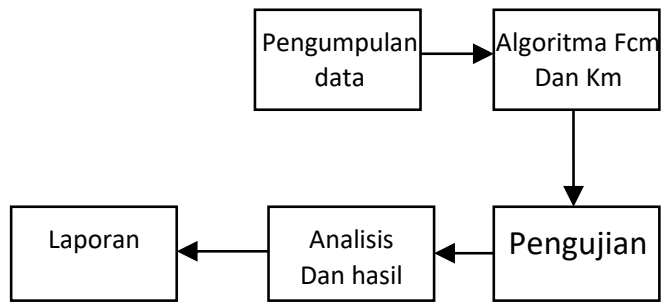

Gambar 2.1 Sistematika Penelitian 


\subsection{Metode Pengumpulan Data}

Data penelitian dapat dikelompokkan menjadi dua jenis yaitu data primer dan data sekunder. Pemahaman terhadap kedua jenis data tersebut diperlukan sebagai landasan dalam menentukan teknik serta langkahlangkah pengumpulan data penelitian.

1. Data Primer atau data asliyang diperoleh atau dikumpulkan secara langsung dari sumber datanya. Untuk mendapatkan data primer, peneliti harus mengumpulkannya secara langsung. Teknik yang dapat digunakan peneliti untuk mengumpulkan data primer antara lain observasi, wawancara, diskusi terfokus.

2. Data Sekunder data yang diperoleh atau dikumpulkan peneliti dari berbagai sumber yang telah ada.Data sekunder dapat diperoleh dari berbagai sumber seperti buku, laporan, jurnal, skripsi dan tesis.

\subsection{Data Uji}

Data uji yang dapat digunakan dalam kasus ini adalah berupa citra atau image, baik citra berwarna maupun citra grayscale. Dalam penelitian ini citra yang diujikan adalah citra berwarna. Ada 6 buah citra uji yang disediakan antara lain :
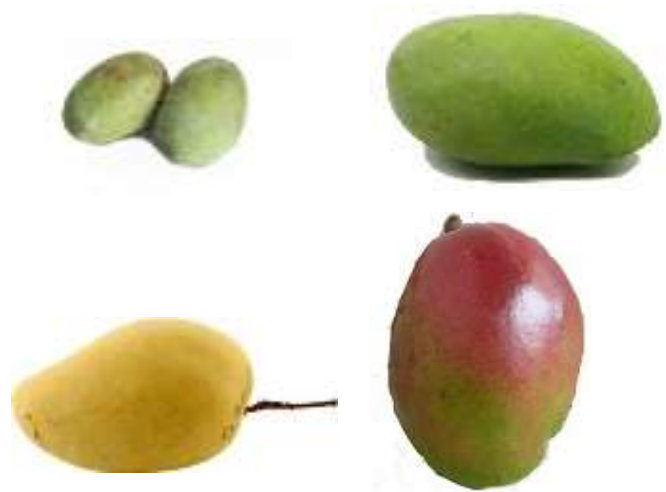
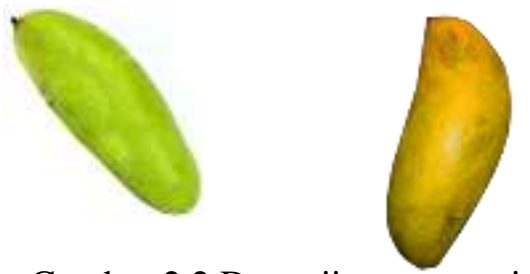

Gambar 2.2 Data uji segmentasi Citra berupa buah mangga

Masing-masing dari data uji diatas dilakukan ekstraksi ciri-ciri meliputi analisis bentuk dan tekstur dengan menggunakan Metode GLCM ( Gray Level Co-Occurrence Matrix). Hasil ekstraksi ciri tersebut sebagai pembanding hasil segmentasi dengan metode K-Means dan Fuzzy C-Means.

\subsection{CIELab}

Warna adalah deskriptor kuat dalam segmentasi citra yang menyederhanakan identifikasi objek dan ekstraksi dari gambar [4]. Model warna memfasilitasi spesifikasi warna dengan cara yang standar. Sebuah subruang sebuah model warna memberikan satu titik untuk mewakili warna.

CIELab adalah salah satu struktur warna yang didefinisikan CIE (Commicion International de 1 'Eclairage/The International Commission on Illumination pada tahun 1976 (CIE 1976 L*a*b*). Pada CIELab, besaran $C I E \_L^{*}$ untuk mendeskripsikan kecerahan warna, 0 untuk hitam dan $\mathrm{L}^{*}=$ 100 untuk putih. Dimensi CIE_a* mendeskripsikan jenis warna hijau merah, dimana angka negatif a* mengindikasikan warna hijau dan sebaliknya CIE_a* positif mengindikasikan warna merah. Dimensi $C I E \_$b* untuk jenis warna biru - kuning, dimana angka negatif $b^{*}$ mengindikasikan warna biru dan sebaliknya CIE_b* positif mengindikasikan warna kuning[4]. 


\subsection{Segmentasi Citra}

Segmentasi merupakan teknik untuk membagi suatu citra menjadi beberapa daerah (region) dimana setiap daerah memiliki kemiripan atribut [6].Pengolahan citra digital merupakan sebuah disiplin ilmu yang mempelajari hal-hal yang berkaitan dengan perbaikan kualitas gambar (peningkatan kontras, transformasi warna, restorasi citra), transformasi gambar(rotasi, translasi, skala, transformasi geometrik), melakukan pemilihan citra ciri(feature images) yang optimal untuk tujuan analisis, melakukan proses penarikaninformasi atau deskripsi objek atau pengenalan objek yang terkandung pada citra,melakukan kompresi atau reduksi data untuk tujuan penyimpanan data, transmisidata, dan waktu proses data. Input dari pengolahan citra adalah citra, sedangkanoutput-nya adalah citra hasil pengolahan.

Metode segmentasi citra dikelompokkan menjadi dua bagian, yaitu metode segmentasi low level dan high level. Metode segmentasi low level misalnya mean shift,watershed, level set, dan super pixel biasanya membagi gambar menjadi beberapa daerah kecil. Meskipun hasil segmentasinya sering over segmentation, namun metode segmentasi low level memberikan dasar yang bagus untuk operasi segmentasi high level selanjutnya. Metode segmentasi high level misalnya region merging, graph cut [7].

\subsection{Segmentasi Citra Berbasis Clustering}

Segmentasi citra berbasis clustering menggunakan data multi dimensi untuk mengelompokkan piksel citra ke dalam beberapa clustering. Data multidimensi pada citra ini maksudnya adalah banyaknya atribut atau komponen penyusun suatu citra, misalnya citra grayscale mempunyai satu buah dimensi,citra RGB mempunyai tiga buah dimensi, dan sebagainya. Pada umumnya pikseldi-clustering berdasarkan kedekatan jarak antar piksel. Segmentasi berbasisclustering ini mulai populer sejak diimplementasikan pada aplikasi OCR (OpticalCharacter Recognition), pengenalan sidik jari hingga remote sensing.Keberhasilan dari proses segmentasi berbasis clustering ini ditentukan dari keberhasilan dalam mengelompokkan fitur-fitur yang berdekatan ke dalam satucluster [6].

Metode-metode dalam segmentasi berbasis clustering di antaranya adalah metode iterasi, K-Means, Fuzzy Cmeans, jaringan syaraf Kohonen, dan berbagai teknik cluster lainnya. Salah satu metode yang sangat baik digunakan untuk segmentasi citra adalah Fuzzy CMeans clustering. Fuzzy C-Means ini merupakan algoritma K-means yang diimprovisasi dengan Fuzzy Set Theory dengan menerapkan derajat keanggotaan, dimana satu piksel citra dapat dimiliki olehbeberapa cluster. "Soft" clustering ini memberikan komputasi yang lebih tepatdalam menentukan keanggotaan dari cluster.

\subsection{Algoritma Fuzzy C-Means}

Fuzzy C-Means adalah suatu teknik clustering (pengelompokan) data di mana keberadaan titik-titik data dalam suatu cluster ditentukan oleh derajat keanggotaan. Penentuan titik cluster dilakukan secara berulang-ulang hingga diperoleh data yang akurat berdasarkan derajat keanggotaannya. Perulangan ini didasarkan pada minimalisasi fungsi obyektif yang meng-gambarkan jarak dari titik data ke pusat cluster yang terbobot oleh derajat keanggotaan. Akibat adanya derajat keanggotaan tersebut, maka suatu titik data bisa dimiliki lebih dari satu kelompok. Metode ini merupakan minimasi dari fungsi objektif [8]. 
kali Algoritma Fuzzy C Means pertama (1974),kemudian dikembangkan oleh Bezdek (1981), kemudian direvisi oleh Rouben(1982), Trauwert (1985), Goth dan Geva (1989), Gu dan Gubuisson (1990), Xiedan Beni (1991). Namun, algoritma FCM dari Bezdek yang paling banyakdigunakan. Fuzzy C-Means adalah salah satu teknik pengelompokkan data yangmana keberadaan tiap titik data dalam suatu kelompok (cluster) ditentukan olehderajat keanggotan. Berbeda dengan k-means clustering, dimana suatu objek hanya akan menjadi anggota satu cluster, dalam Fuzzy CMeans setiap objekdapat menjadi anggota dari beberapa cluster. Batasbatas dalam k-means adalahtegas (hard) sedangkan dalam Fuzzy C-Means adalah soft. Fuzzy C-Means bersifat sederhana, mudah diimplementasikan, memiliki kemampuan untuk mengelompokkan data yang besar, lebih kokoh terhadap data outlier.

\subsection{K-means}

Algoritma K-means merupakan salah satu algoritma dengan partitional, karena K-Means didasarkan pada penentuan jumlah awal kelompok dengan mendefinisikan nilai centroid awalnya [9]. Algoritma K -means menggunakan proses secara berulang-ulang. untuk mendapatkan basis data cluster. Dibutuhkan jumlah cluster awal yang diinginkan sebagai masukan dan menghasilkan titik centroid akhir sebagai output. Metode K-means akan memilih pola k sebagai titik awal centroid secara acak atau random. Jumlah iterasi untuk mencapai cluster centroid akan dipengaruhi oleh calon cluster centroid awal secara random. Sehingga didapat cara dalam pengembangan algoritma dengan menentukan centroid cluster yang dilihat dari kepadatan data awal yang tinggi agar mendapatkan kinerja yang lebih tinggi [10].

\subsection{Ekstraksi Ciri}

Ekstraksi ciri merupakan salah satu tahapan dalam sistem CBIR yangberguna untuk mendapatkan karakteristik visual citra [11]. Ekstraksi ciri adalah proses mengambil ciri-ciri yang terdapat pada citra.Ciri-ciri tersebut adalah besaran komponen tertentu dari citra objek yang mewakilisifat utama citra objek, sekaligus mengurangi dimensi citra objek menjadisekumpulan bilangan yang lebih sedikit tetapi representative [12].

Tujuan utama dari proses ekstraksi ciri adalah untuk mengkarakterisasiobjek yang ingin dikenali dari sebuah citra dengan menggunakan ukuranukuranyang memiliki nilai sangat mirip untuk objek pada kategori yang sama dan sangatberbeda untuk objek pada kategori yang tidak sama.

Tabel 2.1 Formula Ektraksi Ciri Analisis Bentuk

\begin{tabular}{|c|c|c|}
\hline No & Feature & Formula \\
\hline $\mathbf{1}$ & Metric & $M=\frac{4 \pi \times A}{c^{2}}$ \\
\hline $\mathbf{2}$ & Eccentricity & $e=\sqrt{1-\frac{b^{2}}{a^{2}}}$ \\
\hline
\end{tabular}

\subsection{Metode GLCM ( Gray Level Co-}

\section{Occurrence Matrix)}

Metode GLCM merupakan suatu metode yang melakukan analisis terhadap suatu piksel pada citra dan mengetahui tingkat keabuan yang sering terjadi [11]. Metode ini juga untuk tabulasi tentang frekuensi kombinasi nilai piksel yang muncul pada suatu citra. Untuk melakukan analisis citra berdasarkan distribusi statistik dari intensitas pikselnya, dapat dilakukan dengan mengekstrak fitur teksturnya. GLCM merupakan suatu metode untuk 
melakukan ekstraksi ciri berbasis statistikal, perolehan ciri diperoleh dari nilai piksel matrik, yang mempunyai nilai tertentu dan membentuk suatu sudut pola [13].

Berdasarkan kondisi tersebut terlihat bahwa untuk membedakan antar matrik gambar dapat dilihat berdasarkan ciri matrik dengan menggunakan persamaan sebagai berikut;

Tabel 2.2Formula Ekstraksi Ciri

Analisis Tekstur

\begin{tabular}{|l|l|l|}
\hline $\begin{array}{c}\mathrm{N} \\
\mathrm{o}\end{array}$ & Feature & \multicolumn{1}{|c|}{ Formula } \\
\hline 1 & Contras & $\underline{\sum_{i} \sum_{j}(i-j)^{2} C(i, j)}$ \\
\hline 2 & Energy & $\underline{\sum_{i} \sum_{j} C^{2}(i, j)}$ \\
\hline 3 & $\begin{array}{l}\text { Correlati } \\
\text { on }\end{array}$ & $\frac{\sum_{i} \sum_{j} C(i, j) \log (C(i, j)}{}$ \\
\hline 4 & $\begin{array}{l}\text { Homoge } \\
\text { nitas }\end{array}$ & $\frac{\sum_{i} \sum_{j} \frac{C(i, j)}{1+|i+j|}}{}$ \\
\hline
\end{tabular}

\section{Hasil dan Pembahasan}

\subsection{Antarmuka Sistem}

Antarmuka sistem ini berfungsi untuk mempermudah pengoperasian aplikasi segmentasi citra dengan metode K-means dan Fuzzy C-means.

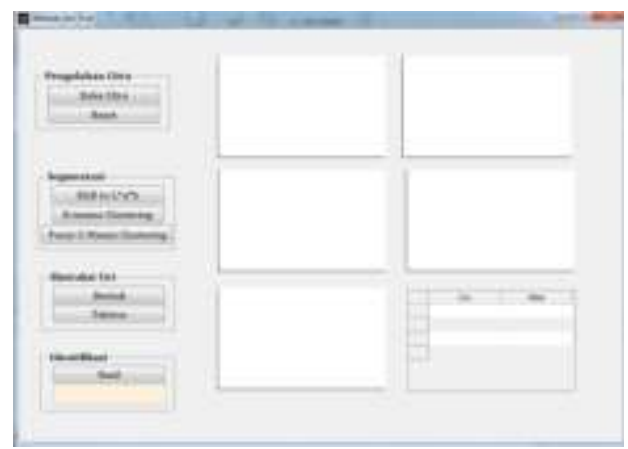

Gambar 3.1 Antarmuka Sistem

Segmentasi Citra

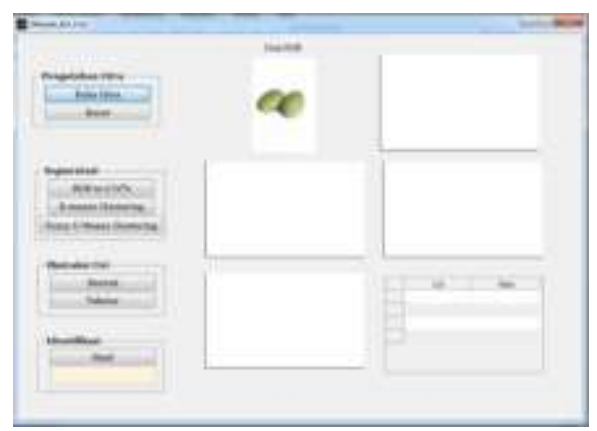

Gambar 3.2. Antarmuka Input Sistem

Segmentasi Citra

Citra uji ditampilkan pada panelutama yang selanjutnya dapat diproses menggunakan metode $\mathrm{KM}$ atau FCM.

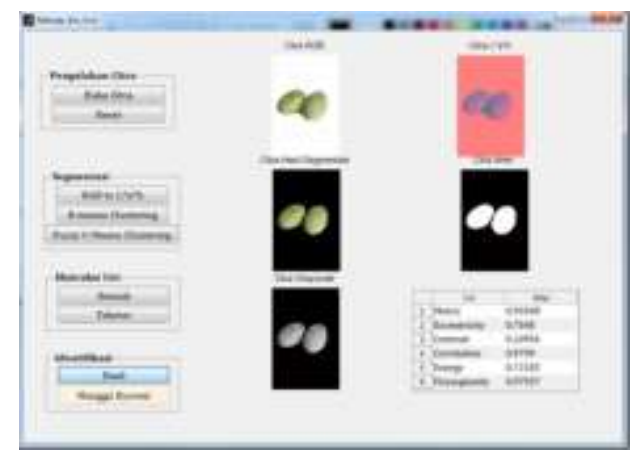

Gambar 3.3 Antarmuka Proses segmentasi citra

Pada Antarmuka gambar di atas, ditampilkan informasi analisis bentuk yaitu parameter metric dan eccentricity, analisis tekstur yaitu parameter contras, correlation, energy dan homogenity. Setelah proses analisis bentuk dan analisis tekstur selesai proses selanjutnya adalah menentukan identifikasi hasil pengenalan pola menggunakan segmentasi KM dan FCM.

\subsection{Hasil Perbandingan K-Means dan Fuzzy C-Means}


Hasil uji coba citra uji Mangga menggunakan algoritma K-Means dan Fuzzy C-Means ditampilkan pada gambar 3.4 dangambar 3.5 di bawahini.

\subsubsection{Hasil Uji Mangga menggunakan} K-Means

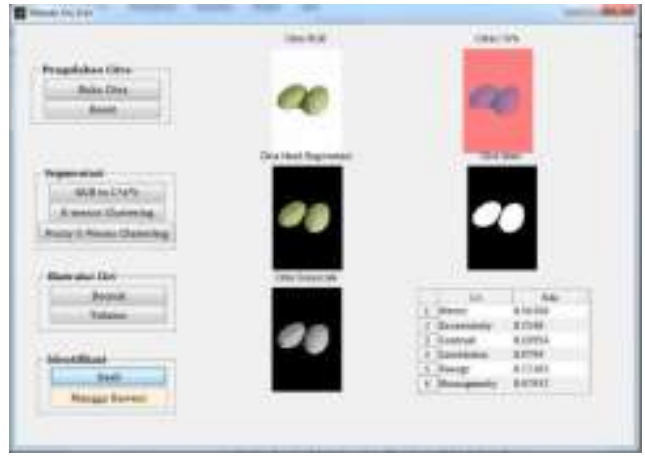

Gambar 3.4 Hasil uji manga menggunakan K-Means

\subsubsection{Hasil Uji Mangga menggunakan Fuzzy C-Means}

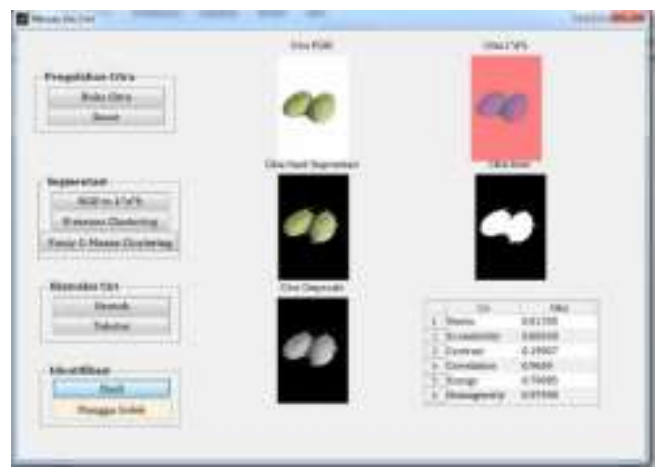

Gambar 3.5 Hasil uji mangga menggunakan Fuzzy C-Means

\subsection{Hasil Analisa Tekstur dan Analisa Bentuk}

Perbandingan

Analisis

Bentukmeliputimetric dan eccentricity sedangkan Analisis Tekstur meliputi contras, correlation, energy dan homogeneity. Hasil perbandingan analisi ini dapat dilihat pada tabel dibawah ini.
Tabel 3.3 Perbandingan Analisis

Bentuk dan Analisis TeksturK-Means

Dan Fuzzy C-Means.

\begin{tabular}{|c|c|c|c|}
\hline Citra Uji & Metode & Metric & $\begin{array}{c}\text { Eccentrici } \\
\text { ty }\end{array}$ \\
\hline \multirow{3}{*}{$\begin{array}{l}\text { Mangga } \\
\text { Kuweni }\end{array}$} & KM & 0.90308 & 0.7548 \\
\hline & FCM & 0.51205 & 0.85058 \\
\hline & Citra & 0.9031 & 0.7548 \\
\hline \multirow{3}{*}{$\begin{array}{l}\text { Mangga } \\
\text { Arum } \\
\text { Manis }\end{array}$} & KM & 0.87694 & 0.83087 \\
\hline & FCM & 0.83544 & 0.79919 \\
\hline & Citra & 0.8769 & 0.7992 \\
\hline \multirow{3}{*}{$\begin{array}{c}\text { Mangga } \\
\text { Chokana } \\
\text { n }\end{array}$} & KM & 0.88782 & 0.77769 \\
\hline & FCM & 0.52817 & 0.79786 \\
\hline & Citra & 0.8878 & 0.7777 \\
\hline \multirow{3}{*}{$\begin{array}{c}\text { Mangga } \\
\text { Madu } \\
\text { Afrika }\end{array}$} & KM & 0.91135 & 0.69738 \\
\hline & FCM & 0.79964 & 0.69916 \\
\hline & Citra & 0.9113 & 0.6974 \\
\hline \multirow{3}{*}{$\begin{array}{l}\text { Mangga } \\
\text { Golek }\end{array}$} & $\mathrm{KM}$ & 0.68981 & 0.9295 \\
\hline & FCM & 0.66267 & 0.9305 \\
\hline & Citra & 0.6628 & 0.9305 \\
\hline \multirow{3}{*}{$\begin{array}{c}\text { Mangga } \\
\text { Golek } \\
\text { India }\end{array}$} & KM & 0.70661 & 0.91061 \\
\hline & FCM & 0.72327 & 0.91115 \\
\hline & Citra & 0.7066 & 0.91115 \\
\hline
\end{tabular}

\begin{tabular}{|c|c|c|c|}
\hline Citra Uji & Metode & Contras & $\begin{array}{c}\text { Correlati } \\
\text { on }\end{array}$ \\
\hline \multirow{2}{*}{$\begin{array}{c}\text { Mangga } \\
\text { Kuweni }\end{array}$} & KM & 0.10954 & 0.9799 \\
\cline { 2 - 4 } & FCM & 0.19907 & 0.9654 \\
\cline { 2 - 4 } & Citra & 0.1095 & 0.9799 \\
\hline \multirow{2}{*}{} & KM & 0.13746 & 0.97415 \\
\cline { 2 - 4 } & FCM & 0.13972 & 0.97347 \\
\hline
\end{tabular}




\begin{tabular}{|c|c|c|c|}
\hline $\begin{array}{c}\text { Mangga } \\
\text { Arum } \\
\text { Manis }\end{array}$ & Citra & 0.1375 & 0.9742 \\
\hline \multirow{2}{*}{$\begin{array}{c}\text { Mangga } \\
\text { Chokana } \\
n\end{array}$} & FCM & 0.29454 & 0.97311 \\
\cline { 2 - 4 } & Citra & 0.2945 & 0.9731 \\
\hline \multirow{2}{*}{$\begin{array}{c}\text { Mangga } \\
\text { Madu } \\
\text { Afrika }\end{array}$} & KM & 0.13939 & 0.96935 \\
\cline { 2 - 4 } & Citra & 0.14327 & 0.96846 \\
\hline \multirow{2}{*}{$\begin{array}{c}\text { Mangga } \\
\text { Golek }\end{array}$} & KM & 0.1394 & 0.9694 \\
\cline { 2 - 4 } & FCM & 0.19896 & 0.97889 \\
\cline { 2 - 4 } & Citra & 0.1989 & 0.9778 \\
\hline \multirow{2}{*}{$\begin{array}{c}\text { India } \\
\text { Gangga }\end{array}$} & KM & 0.08422 & 0.98713 \\
\cline { 2 - 4 } & FCM & 0.08065 & 0.98766 \\
\hline \multirow{2}{*}{$\begin{array}{c}\text { Citra } \\
\text { Kan }\end{array}$} & 0.08065 & 0.9871 \\
\hline
\end{tabular}

\begin{tabular}{|c|c|c|c|}
\hline & Citra & 0.5545 & 0.96071 \\
\hline Mangga & $\mathrm{KM}$ & 0.5545 & 0.9607 \\
Golek & & & \\
\cline { 2 - 4 } India & FCM & 0.55703 & 0.96702 \\
\cline { 2 - 4 } & Citra & 0.55249 & 0.9665 \\
\hline & & 0.5570 & 0.9670 \\
\hline
\end{tabular}

\begin{tabular}{|c|c|c|c|}
\hline Citra Uji & Metode & Energy & $\begin{array}{c}\text { Homoge } \\
\text { nity }\end{array}$ \\
\hline \multirow{3}{*}{$\begin{array}{l}\text { Mangga } \\
\text { Kuweni }\end{array}$} & KM & 0.72183 & 0.97937 \\
\hline & FCM & 0.70085 & 0.97598 \\
\hline & Citra & 0.7218 & 0.9794 \\
\hline \multirow{3}{*}{$\begin{array}{c}\text { Mangga } \\
\text { Arum } \\
\text { Manis }\end{array}$} & KM & 0.54009 & 0.96947 \\
\hline & FCM & 0.52247 & 0.96811 \\
\hline & Citra & 0.5401 & 0.9695 \\
\hline \multirow{3}{*}{$\begin{array}{c}\text { Mangga } \\
\text { Chokana } \\
\text { n }\end{array}$} & KM & 0.2776 & 0.96468 \\
\hline & FCM & 0.27497 & 0.96259 \\
\hline & Citra & 0.2776 & 0.9647 \\
\hline \multirow{3}{*}{$\begin{array}{c}\text { Mangga } \\
\text { Madu } \\
\text { Afrika }\end{array}$} & KM & 0.44633 & 0.97351 \\
\hline & FCM & & \\
\hline & Citra & 0.44414 & 0.97291 \\
\hline \multirow{2}{*}{$\begin{array}{c}\text { Mangga } \\
\text { Golek }\end{array}$} & KM & 0.4463 & 0.9735 \\
\hline & FCM & 0.55391 & 0.96057 \\
\hline
\end{tabular}

\subsection{Hasil Analisa Identifikasi}

Perbandingan hasil identifikasi dari Mangga menggunakan algoritma KMeans dan Fuzzy C-Means ditampilkan pada pada tabel 2 dibawah ini.

Tabel 3.4 Perbandingan Hasil Identifikasi

\begin{tabular}{|c|c|c|c|}
\hline Citra Uji & $\begin{array}{c}\text { Metod } \\
\text { e }\end{array}$ & $\begin{array}{c}\text { Identifikas } \\
\mathbf{i}\end{array}$ & $\begin{array}{c}\text { Ket } \\
\text {. }\end{array}$ \\
\hline \multirow{2}{*}{$\begin{array}{l}\text { Mangga } \\
\text { Kuweni }\end{array}$} & KM & $\begin{array}{l}\text { Mangga } \\
\text { Kuweni }\end{array}$ & $\sqrt{ }$ \\
\hline & FCM & $\begin{array}{l}\text { Mangga } \\
\text { Golek }\end{array}$ & $\mathrm{X}$ \\
\hline \multirow{2}{*}{$\begin{array}{l}\text { Mangga } \\
\text { Arum } \\
\text { Manis }\end{array}$} & KM & $\begin{array}{l}\text { Mangga } \\
\text { Arum } \\
\text { Manis }\end{array}$ & $\sqrt{ }$ \\
\hline & FCM & $\begin{array}{l}\text { Mangga } \\
\text { Arum } \\
\text { Manis }\end{array}$ & $\sqrt{ }$ \\
\hline \multirow{2}{*}{$\begin{array}{l}\text { Mangga } \\
\text { Chokana } \\
\text { n }\end{array}$} & KM & $\begin{array}{l}\text { Mangga } \\
\text { Chokanan }\end{array}$ & $\sqrt{ }$ \\
\hline & FCM & $\begin{array}{l}\text { Mangga } \\
\text { Golden } \\
\text { Water Lily }\end{array}$ & $\mathrm{x}$ \\
\hline \multirow{2}{*}{$\begin{array}{l}\text { Mangga } \\
\text { Madu } \\
\text { Afrika }\end{array}$} & KM & $\begin{array}{l}\text { Mangga } \\
\text { Madu } \\
\text { Afrika }\end{array}$ & $\sqrt{ }$ \\
\hline & FCM & $\begin{array}{l}\text { Mangga } \\
\text { Madu } \\
\text { Afrika }\end{array}$ & $\sqrt{ }$ \\
\hline \multirow{2}{*}{$\begin{array}{l}\text { Mangga } \\
\text { Golek }\end{array}$} & KM & $\begin{array}{l}\text { Mangga } \\
\text { Golek }\end{array}$ & $\sqrt{ }$ \\
\hline & FCM & $\begin{array}{l}\text { Mangga } \\
\text { Golek }\end{array}$ & $\sqrt{ }$ \\
\hline \multirow{2}{*}{$\begin{array}{l}\text { Mangga } \\
\text { Golek } \\
\text { India }\end{array}$} & KM & $\begin{array}{l}\text { Mangga } \\
\text { Golek India }\end{array}$ & $\sqrt{ }$ \\
\hline & FCM & $\begin{array}{l}\text { Mangga } \\
\text { Golek India }\end{array}$ & $\sqrt{ }$ \\
\hline
\end{tabular}


Berdasarkan tabel hasil identifikasi dapat dilihat bahwa hasil segmentasi dengan metode K-Means menghasilkan identifikasi yang akurat. Sedangkan untuk metode Fuzzy C-Means terlihat "Mangga Kuweni" di identifikasi dengan "Mangga Golek" dan "Mangga Chokanan" di identifikasi dengan "Mangga Golden Water Lily". Hal ini menunjukan bahwa metode K-means menghasilkan hasil identifikasi yang lebih akurat dari metode Fuzzy C-Means.

\section{Simpulan}

Berdasarkan uji coba yang telah dilakukan dalam penelitian ini dapat disimpulkan bahwa dalam segmentasi untuk identifikasi pola menggunakan analisis tekstur dan analisis bentuk, hasil segmentasi dengan metode K-Means lebih baik daripada dengan metode Fuzzy C-Means. Untuk saran penelitian selanjutnya bias digunakan lebih dari 2 metode serta objek penelitian selain buah mangga.

\section{DaftarPustaka}

[1] Gunawan, F Alim. \&Erni W.,2011.Perangkat Lunak Segmentasi Citra Dengan Metode Watershed. JSIFO STMIK Mikroskil.Vol.12-No.2, Pp.79-88.

[2] Amiya Halder, Soumajit Pramanik. 2011. Dynamic Image Segmentation Using Fuzzy C-Means Based Genetic Algorithm. International Journal Of Computer Application, Vol. 28-No.6,Pp.15-20

[3] Arthur, D. danVassilvitskii, S. 2006.How Slow is the k-Means Method, Stanford University, Stanford, CA.

[4] Rasmana.

Susijanti Tri,.2013.Peningkatan Kualitas Citra Prasasti Logam Berbasis Klasifikasi Fitur Warna Menggunakan Support Vector Machine, Proposal Desertasi Istitut
Teknologi Sepuluh Nopember Surabaya.

[5] Gernot Hoffmann, CIE Color Space, 2010.

[6] Darma Putra. 2010. Pengolahan Citra Digital. Yogyakarta : ANDI Offset

[7] Ning, J., Zhang, D., Wu, Chengke. 2009. Interactive Image Segmentation by Maximal Similarity Based Region Merging, pp. 445456.

[9] Madhulatha, T.S., 2012. An Overview On Clustering Methods. Iosr Journal Of Engineering, Ii(1), Pp.719-725.

[10] B. Sowmya, B. Sheela Rani. 2010. Colour image segmentation using fuzzy clustering techniques and competitive neural network, Elsevier Applied Soft Computing ScienceDirect. Sathyabama University, Old Mamallapuram Road, Chennai 600119, India

[11]Herdiyeni, Y dan Widyanto, M. R. 2007. Sistem Temu Kembali Citra DenganUkuranKemiripan Warna Dalam Ruang RGB Berbasis Sistem Inferensi Fuzzy. Proceedings of National Conference on Computer Science andInformation Technology. Fakultas IlmuKomputer.

UniversitasIndonesia.Jakarta

[12] Syahputra, H. 2009. Ekstraksi Fitur Menggunakan Elliptical Fourier DescriptoruntukPengenalan Varietas Tanaman Kedelai. Institut Pertanian Bogor.Bogor

[13] Xie, Q., Huang ,D., Zhang,S.,Dan Cao,J., (2010), Analysis of A Viral Infection Model With Delayed Immune Response, Applied Mathematical Modelling , 34, Hal.2388-2395 